\title{
Late-replicating X-chromosome: replication patterns in mammalian females
}

\author{
Karen Tunin ${ }^{1,2}$ and Priscila Guimarães Otto ${ }^{1}$ \\ ${ }^{1}$ Departamento de Biologia, Instituto de Biociências, Universidade de São Paulo, São Paulo, Brazil. \\ ${ }^{2}$ Laboratório de Biotecnologia Animal, Escola Superior de Agronomia Luiz de Queiroz, \\ Universidade de São Paulo, Piracicaba, Brazil.
}

\begin{abstract}
The GTG-banding and 5-BrdU incorporation patterns of the late-replicating X-chromosome were studied in female dogs and cattle, and compared to human female patterns. The replication patterns of the short arm of the X-chromosomes did not show any difference between human, dog and cattle females. As to the long arm, some bands showed differences among the three studied species regarding the replication kinetics pattern. These differences were observed in a restricted region of the X-chromosome, delimited by Xq11 $\rightarrow$ q25 in humans, by $\mathrm{Xq} 1 \rightarrow \mathrm{q} 8$ in dogs, and by Xq12 $\rightarrow$ q32 in cattle. In an attempt to find out if these differences in the replication kinetics could be a reflection of differences in the localization of genes in that region of the X-chromosome, we used the probe for the human androgen receptor gene (AR) localized at Xq12, which is in the region where we observed differences among the three studied species. We did not, however, observe hybridization signals. Our study goes on, using other human probes for genes located in the region $\mathrm{Xq} 11 \rightarrow \mathrm{Xq} 25$.
\end{abstract}

Key words: X-chromosome, replication patterns, mammalian females.

Received: April 4, 2002; accepted: July 22, 2002.

\section{Introduction}

According to Ohno (1994), all placental mammals of today descended from a common stock of protoinsectivores that emerged at the dawn of the Cenozoic era. Extensive speciation from a common ancestor was accomplished without substantial change in the total DNA content, and almost exclusively by allelic mutation of individual gene loci, with little or no change in the total number of gene loci. The autosomes have broken and reunited many times, but the X-chromosome has not been involved in shuffling, and apparently persisted without substantial change from its beginning.

A variety of evidence revealed that the differentiation of the $\mathrm{X}$ and $\mathrm{Y}$ chromosomes from a homologous pair was accomplished at the expense of the heterogametic sex determiner. While the $\mathrm{Y}$ shed mendelian genes that were originally located on it, the $\mathrm{X}$ conserved all these genes. Conservation of the original $\mathrm{X}$ within the stable genome implies that there should be extensive homology of the $\mathrm{X}$-linked genes among placental mammals, for so-called $\mathrm{X}$-linked genes are the mendelian genes which were al-

Send correspondence to Priscila Guimarães Otto. Departamento de Biologia, Instituto de Biociências, Universidade de São Paulo, Rua do Matão 277, Cidade Universitária, 05422-070 São Paulo, SP, Brazil. E-mail: pgotto@usp.br ready there when the $\mathrm{X}$ was merely a member of an ordinary homologous pair (Ohno, 1967).

Marshall-Graves (1987) stated that the gene content (though not the gene order) of divergent eutherian species seems to be conserved. For instance, the constitutively expressed enzymes HPRT (hypoxanthine-phosphoribosyltransferase), PGK (phosphoglycerate-kinase), and GLA ( $\alpha$-galactosidase) are borne by the $\mathrm{X}$ in all primates, rodents, carnivores, ungulates and artiodactyls in which they have been studied. Other genes, X-linked at least in man and mouse, are OTC (ornithine-transcarbamilase) and STS (steroid-sulfatase). The gene for Canine Muscular Dystrophy (CXMD) is also X-linked (Cooper et al., 1988).

According to Schmidt et al. (1982), the human genome is replicated in two phases: in the early $\mathrm{S}$ period, the $\mathrm{R}$-bands are replicating, while in the late $\mathrm{S}$ period, predominantly G-band DNA is synthesized. However, in C-positive polymorphic regions of the chromosomes, as well as in the inactive $\mathrm{X}$ and in the $\mathrm{Y}$ chromosome, DNA replication seems to escape the general rule. In the inactive $\mathrm{X}$-chromosome, initiation and termination of the process are delayed with regard to its homologue. The whole process seems to proceed mostly during the late part of the $\mathrm{S}$ phase, and the DNA synthesis rate is higher than in the active X-chromosome. 
Dutrillaux et al. (1973) showed that the administration of 5-bromodeoxyuridine (5-BrdU) as a terminal pulse results in the decondensation of the late-replicating regions of all chromosomes and of the late-replicating X-chromosome in female cells.

Miyake (1982) studied bovine cells and showed that the two X-chromosomes of the female complement had different replicating patterns, and that the X-chromosome of the male had a replicating pattern similar to one of the two $\mathrm{X}$-chromosomes of the female.

According to McCaw and Latt (1977), two types of replication kinetics exist in the inactive X-chromosome of human lymphocytes. Otto (1979) also described two types of replication kinetics for the inactive $\mathrm{X}$-chromosome: type $\mathrm{I}$, in which band Xq23 is later than Xq27, and both are later than Xq28; and type II, in which band Xq27 is later than $\mathrm{Xq} 28$, and both are later than $\mathrm{Xq} 23$.

With these facts in mind, the objectives of the present project were to study the GTG-banding and 5-BrdU incorporation patterns in the late-replicating X-chromosome of domestic mammal females, to compare the findings with the replicating patterns of the human late X-chromosome, and to start a comparative study by FISH about the localization of genes on the X-chromosome in different species.

\section{Material and Methods}

Eight cows and six bitches were studied. The blood samples were obtained from "Hospital Veterinário" of the "Faculdade de Medicina Veterinária e Zootecnia" (FMVZ) of the University of São Paulo. Blood cultures were performed at the Cytogenetics Laboratory of the Animal Reproduction Department (FMVZ), and the analyses were performed at the Human Genetics Laboratory of the Biology Department of the Institute for Biosciences of the University of São Paulo.

\section{Lymphocyte cultures}

Bovine chromosome analysis was performed on peripheral blood lymphocytes cultured as described by Halnam (1989), with modifications: $0.5 \mathrm{~mL}$ of blood were added to $4.5 \mathrm{~mL}$ of TC199 culture medium (Gibco-BRL) enriched with 15\% fetal bovine serum (CULTILAB), 1\% phytohemagglutinin (Gibco-BRL) and 1\% glutamin (Gibco-BRL). After a $72 \mathrm{~h}$ incubation at $39{ }^{\circ} \mathrm{C}, 50 \mu \mathrm{L}$ of $4 \times 10^{-5}$ Colcemid (Sigma) were added, and the cultures were let to rest for $50 \mathrm{~min}$. Hypotonization was achieved with $5 \mathrm{~mL}$ of $\mathrm{KCL}(75 \mathrm{mM})$, at $37^{\circ} \mathrm{C}$ for $12 \mathrm{~min}$. Cells were fixed in 3:1 methanol : acetic acid.

Canine chromosome analysis was performed as described above, with the following modifications: $1 \%$ Pokeweed (Sigma) was used as a mitogenic agent, and 1\% penicillin/streptomycin was added to the culture medium. Each culture was set up with $0.5 \mathrm{~mL}$ of plasma and three or four drops of blood. The time used for incubation with Colcemid was $40 \mathrm{~min}$.

\section{GTG-banding}

Was performed, as described by Seabright (1971), on 3-weeks-old metaphase chromosomes, obtained according to the method described above.

\section{5-BrdU incorporation}

Metaphase chromosomes were obtained as described above and, following a modification of the procedure described by Zakharov and Egolina (1976), $100 \mu \mathrm{g} / \mathrm{mL}$ of 5-BrdU were added seven hours before harvesting. Slides were stained with Hoechst $33258(5 \mu \mathrm{g} / \mathrm{mL})$, and exposed to UV light (30W, $254 \mathrm{~nm}$ ) for 10-12 min. Then the slides were stained with Giemsa (Merck) at 1.5-2.0\%.

\section{Fish}

The slides were washed one by one, and then 2 drops of each culture (dogs and bovine females) were sprinkled onto the slides. The slides were then stored for at least 10 days in a plastic box. After this period of time, the slides were removed to a freezer and left to age at $-20{ }^{\circ} \mathrm{C}$ for 2 more weeks. Then, the slides were immersed in $2 \mathrm{xSSC}$ at $37{ }^{\circ} \mathrm{C}$ for $20 \mathrm{~min}$, followed by 4 different baths at room temperature: 2xSSC pH 7; alcohol 50\%; alcohol 70\% and absolute ethanol p.a.. The slides were then dried at room temperature and immersed in a solution of formamide (70\%), 20xSSC (20\%) and MilliQ water (10\%) at $70 \pm 2{ }^{\circ} \mathrm{C}$, for $5 \mathrm{~min}$, and then dehydrated in successive baths of $2 \mathrm{xSSC}$ pH 7; chilled alcohol $50 \%$; chilled alcohol $70 \%$ and chilled absolute ethanol p.a. The slides were then dried at room temperature, and $10 \mu \mathrm{L}$ of probe (AR gene probe DNS SO LSI, Vysis, Inc) were poured onto them, and covered with a plastic coverslip. Then all the slides were incubated for 5 days in a dry box at $37^{\circ} \mathrm{C}$. For washing, 3 different protocols have been used: (1) IB/USP Human Genetics Lab protocol: formamide $50 \%+2 \mathrm{xSSC}$ at $37^{\circ} \mathrm{C}$ for $5 \mathrm{~min}$ (three baths), $2 \mathrm{xSSC}$ at $37{ }^{\circ} \mathrm{C}$ for $5 \mathrm{~min}$ (one bath), and PBT at room temperature for $5 \mathrm{~min}$ (two baths); (2) Vysis protocol (modified): formamide $50 \%+2 \mathrm{xSSC}$ at $37^{\circ} \mathrm{C}$ for $5 \mathrm{~min}$ (two baths), $2 \mathrm{xSSC}$ at $37^{\circ} \mathrm{C}$ for $5 \mathrm{~min}$ (one bath), and PBT at room temperature for $5 \mathrm{~min}$ (one bath); (3) Park (1996) protocol (modified): formamide 40\%+ $12 \mathrm{xSSC}$ at $37^{\circ} \mathrm{C}$ for $30 \mathrm{~min}$ (one bath), $2 \mathrm{xSSC}$ at $37^{\circ} \mathrm{C}$ for $10 \mathrm{~min}$ (one bath), and PBT at room temperature for $5 \mathrm{~min}$ (three baths). After the washing, the slides were covered with approximately $10 \mathrm{~mL}$ of PPD + DAPI (500:1) and a glass coverslip, and taken to a dark room. The observations were made by means of a Zeiss Axiophot fluorescence microscope; pictures were taken with Kodachrome 400 (Kodak) film or captured with a CCD camera and processed by ISIS (Metasystem) software. 


\section{Results and Discussion}

In the present sample of female dogs, we observed three different patterns of 5-BrdU incorporation in the late $\mathrm{X}$-chromosome. However, taking into account that the lymphocytes were not synchronized, and therefore not at the same point of DNA synthesis when 5-BrdU was added, the three different patterns can be arranged in one logical sequence (Figure 1), suggesting that in dogs there is only one type of replication kinetics.

The 5-BrdU incorporation patterns of the latereplicating X-chromosomes observed in our sample of cows (Figure 2) did not indicate the existence of two differ-

When 5-BrdU was added, the cell was at:

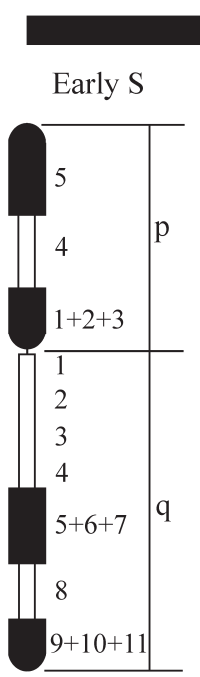

Late S
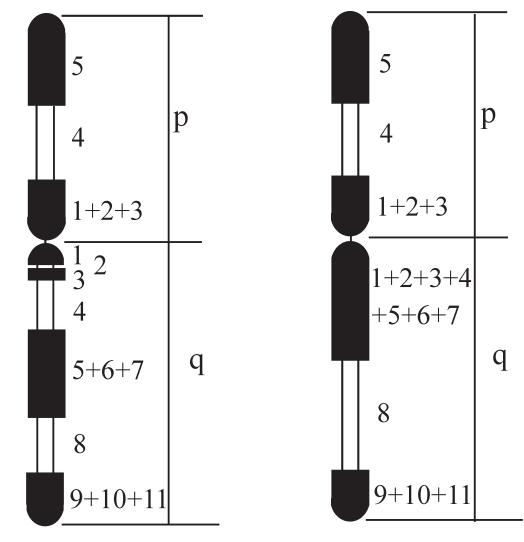

Figure 1 - Replication patterns in late-replicating female dog X-chromosome, after BrdU incorporation, arranged in such a sequence as to allow for the fact that the lymphocytes were not at the same point of DNA synthesis when BrdU was added. ent types of replication kinetics, and are consistent with the patterns described by Miyake (1982) for bovine late replicating X-chromosomes.

The observed replication patterns of the short arm of the X-chromosomes of human, dog and cattle females did not show any difference. As to the long arm, the three studied species showed different replication kinetics at some bands (Table I). Dog band Xq8 and cattle band Xq32 replicate much later than the corresponding human band Xq25; dog band Xq2 and cattle band Xq12 replicate somewhat later than the corresponding human band $\mathrm{Xq} 12$, and dog band $\mathrm{Xq} 4$ and human band $\mathrm{Xq} 21$ replicate later than the corresponding cattle band Xq22. These observations indicate differences in the replication kinetics of a restricted region of the X-chromosome, delimited by Xq11 $\rightarrow$ q25 in humans, by Xq1 $\rightarrow$ q8 in dogs, and by Xq12 $\rightarrow$ q32 in cattle (Figure 3).

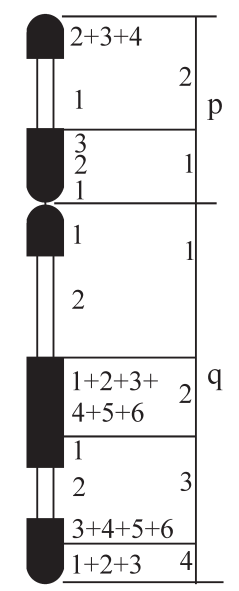

Figure 2 - Replication patterns in late-replicating female cattle X-chromosome, after 5-BrdU incorporation.

Table I - Late X-chromosome replication kinetics, as observed in humans (Otto, 1979), dogs and cattle (present paper).

\begin{tabular}{|c|c|c|c|c|c|}
\hline \multirow{2}{*}{$\begin{array}{l}\text { 5-BrdU } \\
\text { Added at: }\end{array}$} & \multicolumn{2}{|c|}{ Human } & \multirow[t]{2}{*}{ Dog } & \multirow[t]{2}{*}{ Cattle } & \multirow[t]{2}{*}{ Replication } \\
\hline & Type I & Type II & & & \\
\hline $\begin{array}{l}\text { very early } \\
\text { S phase }\end{array}$ & $\begin{array}{l}\mathrm{p} 22-\mathrm{p} 11-\mathrm{q} 11-\mathrm{q} 13- \\
\mathrm{q} 26\end{array}$ & $\begin{array}{l}\mathrm{p} 22-\mathrm{p} 11-\mathrm{q} 11-\mathrm{q} 13- \\
\mathrm{q} 26\end{array}$ & $\begin{array}{l}\mathrm{p} 1-\mathrm{p} 3-\mathrm{p} 5-\mathrm{q} 5-\mathrm{q} 7- \\
\mathrm{q} 9-\mathrm{q} 11\end{array}$ & $\begin{array}{l}\mathrm{p} 24-\mathrm{p} 22-\mathrm{p} 11-\mathrm{p} 13- \\
\mathrm{q} 11-\mathrm{q} 21-\mathrm{q} 23-\mathrm{q} 25- \\
\mathrm{q} 31-\mathrm{q} 33-\mathrm{q} 35-\mathrm{q} 41- \\
\mathrm{q} 43\end{array}$ & Early \\
\hline & $\mathrm{q} 22-\mathrm{q} 24-\mathrm{q} 28$ & $\mathrm{q} 22-\mathrm{q} 23-\mathrm{q} 24$ & $\mathrm{q} 1-\mathrm{q} 3$ & & \\
\hline & $\mathbf{q} 25$ - q27 & $\mathbf{q} 25$ - q28 & $\mathrm{p} 2-\mathrm{q} 6-\mathrm{q} 10$ & $\begin{array}{l}\text { p23 - p12 - q22 - q24 - } \\
\text { q26 - q34 - q36 - q42 }\end{array}$ & \\
\hline & p21 - q12 - q23 & p21 - q12 - q27 & & & \\
\hline$\nabla$ & $q 21$ & q21 & $q 2-q 4$ & p21 - q12 - q32 & $\downarrow$ \\
\hline
\end{tabular}




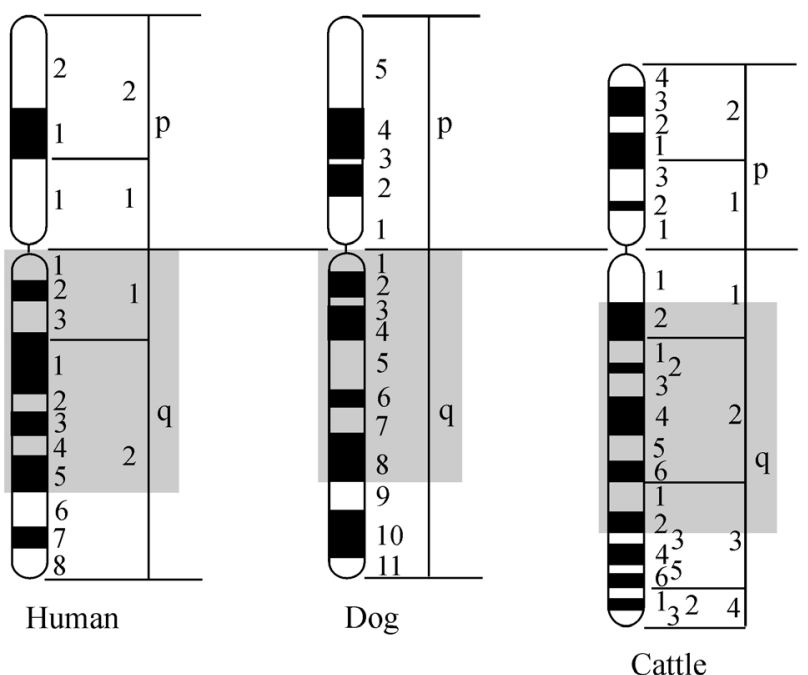

Figure 3 - Region of the late-replicating female X-chromosome, where differences in the replication kinetics pattern were found among humans, dogs and cattle.

In view of these results, we started a comparative study by FISH on the localization of genes comprised by that region of the long arm of the X-chromosome. We used the human probe for the androgen receptor gene (AR) localized at Xq12, which is within the region where we have observed differences in the replication kinetics pattern among the three species studied. We did not, however, observe any hybridization signals. This can be due to technical error, or it can result from a difference between the initial sequence of the human probe and that of dog and cattle genes, or be a reflection of the fact that the AR gene is not perfectly conserved in the three studied species. Solinas-Toldo et al. (1995) remarked that human probes for PGK (Xq13.3) and IL-2RG (Xq13.1) hybridized, respectively, at Xq21-22 and Xq22-23 of cattle X-chromosomes. Using commercial human X-chromosome probes, Goreau et al. (1996) observed complete hybridization on the porcine X-chromosome. Yang et al. (1999) observed homology between dog and human genes CHM and IL-2RG on the long arm of the X-chromosome. The results obtained by O'Brien et al. (1993) and Solinas-Toldo et al. (1995) showed that the X-chromosome is highly conserved, but those studies did not use the AR probe.

Our study will proceed, using other human probes for genes located within region Xq11 $\rightarrow$ Xq25, to find out if the already observed differences in the replication kinetics could be a reflection of differences in the localization of genes in that region of the X-chromosome.

\section{Acknowledgements}

K.T. was the recipient of a "scientific initiation" grant from Fundação de Amparo à Pesquisa do Estado de São Paulo (FAPESP).
The authors thank Ms. Maria R.L. Santana Pinheiro, Laurinda de Fátima P.C. Baptista, Simone A.S. da Fonseca and Ligia S. Vieira for technical assistance.

\section{References}

Cooper BJ, Valentine BA, Wilson S, Patterson DF and Concannon PW (1988) Canine Muscular Dystrophy: confirmation of X-linked inheritance. J Hered 79:405-408.

Dutrillaux B, Laurent C, Couturier J and Lejeune J (1973) Coloration par l'acridine orange des chromosomes préalablement traités par la 5-bromodéoxyuridine. CR Acad Sci 276:3179-3185.

Goreau A, Yerle M, Schmitz A, Riquet J, Milan D, Pinton P, Frelat G and Gellin J (1996) Human and porcine correspondence of chromosome segments using bi-directional chromosome painting. Genomics 36:252-262.

Halnan CRE (1989) Cytogenetics of Animals. UK, CAB International, pp 434-436.

Marshall-Graves JA (1987) The Evolution of Mammalian Sex Chromosomes and Dosage Compensation: clues from marsupials and monotremes. TIG 3(9):252-256.

McCaw BK and Latt SA (1977) X chromosome replication in parthenogenic benign ovarian teratoma. Hum Genet 38:253.

Miyake YI (1982). Studies on replicating patterns of bovine sex chromosomes using 5-bromodeoxyuridine (BrdU). II. Replicating patterns of the late $\mathrm{X}$ chromosome, the early $\mathrm{X}$ chromosome and the $\mathrm{Y}$ chromosome throughout DNA synthesis. Zuchthyg 17:145-150.

O'Brien SJ, Peters J, Searle A, Womack J and Marshall-Graves J (1993) Report of the committee on comparative gene mapping. Genome Priority Reports 1:758-809.

Ohno S (1967) Sex chromosomes and the sex-linked genes. Springer-Verlag, NY pp 46-73.

Ohno S (1994) Conservation of the X-linkage group in toto by all Eutherian Mammals. In: Wachtel SS (ed) Molecular Genetics of Sex Determination. Academic Press Inc., California pp 107-121.

Otto PG (1979) Estudo de isocromossomos do X humano. Doctor's Thesis, Instituto de Biociências, USP, São Paulo, Brazil.

Park JP (1996) Shared synteny of human chromosome 17 loci in Canids. Cytogenet Cell Genet 74:133-137.

Seabright M (1971) A rapid banding technique for human chromosomes. Lancet 2:971.

Schmidt M, Stolzmann WM and Baranovskaya LI (1982) Replication variants of the human inactive $\mathrm{X}$ chromosome. Chromosoma 85:405-412.

Solinas-Toldo S, Lengauer C and Fries R (1995) Comparative genome map of human and cattle. Genomics 27:489-496.

Yang F, O'Brien PCM, Milne BS, Graphodatsky AS, Solanky N, Trifonov V, Rens W, Sargan D and Ferguson-Smith MA (1999) A complete comparative chromosome map for the dog, red fox, and human and its integration with canine genetic maps. Genomics 62:189-202.

Zakharov AF and Egolina NA (1976) Correlation between patterns of DNA replication and chromosome banding. Biol Zbl 95:327-331. 